\title{
Cloning of the transmembrane glycoproteins $G$ and $F$ from a Brazilian isolate of bovine respiratory syncytial virus in a prokaryotic system
}

\author{
[Clonagem das glicoproteínas transmembrana G e F de um isolado brasileiro do vírus respiratório \\ sincicial bovino em sistema procarioto] \\ L.H.A. Silva ${ }^{1}$, K.C. Cardoso $^{2}$, M.J. Silva ${ }^{2}$, F.R. Spilki ${ }^{3}$, C.W. Arns ${ }^{1 *}$ \\ ${ }^{1}$ Laboratório de Virologia Animal, Instituto de Biologia - Universidade Estadual de Campinas - UNICAMP \\ Caixa Postal 6109 \\ Rua Monteiro Lobato, 255 \\ 13083-970 - Campinas, SP \\ ${ }^{2}$ Centro de Biologia Molecular e Engenharia Genética - Universidade Estadual de Campinas - UNICAMP \\ Campinas, SP \\ ${ }^{3}$ Laboratório de Microbiologia Molecular, Instituto de Ciências da Saúde, Universidade Feevale, \\ Novo Hamburgo, RS
}

\begin{abstract}
The aim of this work was the cloning of those transmembrane glycoproteins $\mathrm{G}$ and $\mathrm{F}$ from an isolate bovine respiratory syncytial viruses (BRSV) - a Brazilian isolate of BRSV, named BRSV-25-BR in previous studies, in a prokaryotic system to proceed the sequencing of larger genomic fragments. The nucleotide substitutions were confirmed and these clones may also be used in further studies regarding the biological effects of those proteins in vitro and in vivo.
\end{abstract}

Keywords: bovine respiratory syncytial virus, calves, glycoproteins G and F

\section{RESUMO}

O objetivo deste trabalho foi a clonagem das glicoproteínas transmembrana $G$ e F de um isolado de vírus respiratório sincicial bovino (BRSV) - um isolado brasileiro denominado BRSV-25-BR- que já demonstrou possuir mutações em regiões altamente conservadas do gene da proteína $G$ - em sistema procariótico, com o intuito de sequenciar fragmentos genômicos maiores. As substituições de nucleotídeos foram confirmadas e tais clones podem ser utilizados em futuros estudos sobre os efeitos biológicos destas proteínas tanto in vitro como in vivo.

Palavras-chave: vírus respiratório sincicial bovino, bezerros, glicoproteínas G e F

\section{INTRODUCTION}

Bovine respiratory syncytial virus (BRSV) was first isolated in 1967 (Paccaud and Jacquier, 1970) from calves presenting respiratory distress. The distribution of BRSV is worldwide and it causes severe respiratory disease in young calves, characterized by bronchiolitis and interstitial pneumonia. BRSV is closely related to human respiratory syncytial virus (hRSV), which is a major cause of respiratory disease in young children, and the epidemiology and pathogenesis of infection for these viruses are similar (Valarcher and Taylor, 2007).

The BRSV belongs to the genus Pneumovirus, subfamily Pneumovirinae, family Paramyxoviridae, Mononegavirales order (Vainionpää et al., 1989; Larsen, 2000; Easton et al., 2004). Members of the Mononegavirales order possess genomes constituted by a single strand of negative-sense RNA $\rightarrow \$ 3$ ' sense). The subfamily Pneumovirinae of Paramyxoviridae has two genera: the genus Pneumovirus contains bovine (RSV) as well as

Recebido em 23 de agosto de 2010

Aceito em 12 de abril de 2011

E-mail: arns@unicamp.br 
human, caprine, and ovine RSVs and pneumonia virus of mice; the genus Metapneumovirus consists of avian metapneumovirus (aMPV) and human metapneumovirus (hMPV). The genus Metapneumovirus differs from the genus Pneumovirus on the absence of non-structural proteins NS1 and NS2, and in gene order for the F and M2 genes (Collins et al., 2001).

The BRSV virion consists of a nucleocapsid contained within a lipid envelope. The envelope is a lipid bilayer that is derived from the host plasmatic membrane. It contains three virally encoded transmenbrane surface glycoproteins; the attachment protein $(\mathrm{G})$, the fusion protein (F), and the small hydrophobic SH protein (Collins et al., 2001).

The $G$ protein was identified as the major attachment protein because antibodies specific to the $\mathrm{G}$ protein blocked the binding of the virus to cells (Levine et al., 1987), playing an important role in the immune response against BRSV infection (Bastien et al., 1997; Buchholz et al., 2000; Spilki et al., 2006a). The G protein is a heavily glycosylated, type II membrane protein that does not share any sequence or structural homologies with attachment proteins of other paramyxoviruses (Wertz et al., 1985) and lacks haemaglutinating and neuraminidase activities (Easton et al., 2004).

Glycoprotein $G$ is composed of three domains: cytoplasmatic (AA 1-37) transmembrane (AA 38-65) and extracellular ectodomain (AA 66257) (Langedijk et al., 1996). The cytoplasmatic domain is placed inside the viral envelope; the transmembrane domain runs across the cytoplasmatic membrane envelope. Both these sections of the protein are considerably conserved (Stine et al., 1997; Valentova, 2003). The extracellular domain of glycoprotein $G$ is responsible for binding the virus to the sensitive cells, and the greatest differences within all viral proteins are localized there (Lerch et al., 1990). The ectodomain of the virus consists of hydrophobic variable regions and a central conserved region (Doreleijers et al., 1996; Langedijk et al., 1996). The variable regions of the protein are called mucin-like, due to their high content of carbohydrate side-chains bounded to Ser, Thr (O-linked sugars), and Pro (N-linked sugars). The central conserved region is the only relatively fixed and folded part of the ectodomain of RSV-G, containing four conserved cysteine residues which can form two disulphide bridges. It is speculated that this structure may interact with the host immune system, due to its similarity with fractalkines (Doreleijers et al., 1996; Langedijk et al., 1996). A Brazilian isolate has a major substitution of amino acids in this same region (Spilki et al., 2006a), and studies using this peptide may be of interest to discover whether these features may induce differences in the biological effects of the protein in vivo.

Experiments with mutant viruses possessing an induced deletion glycoprotein $G$ coding gene showed that this glycoprotein is not necessary for virus replication in vitro, although its replication is considerably decreased in both cell cultures and the respiratory tract of mice. It also seems that glycoprotein $G$ is not the only virus protein with attachment activity, but both the glycoproteins $\mathrm{G}$ and $\mathrm{F}$ play a role in attachment of the virus to cells (Karger et al., 2001; Techaarpornkul et al., 2001; Teng and Collins, 2002).

The $\mathrm{F}$ protein directs viral penetration through the fusion between the virion envelope and the host cell plasma membrane, delivering the nucleocapsid to the cytoplasm. Later in infection, the $\mathrm{F}$ protein expressed on the cell surface can mediate fusion with neighboring cells and form syncytia. This is a prominent cytophatic effect and is probably an additional mechanism of viral spread (Collins et al., 2001). The protein is synthesized primarily as the uncleaved precursor $\mathrm{F}_{0}$ that is cleaved by cellular proteases in the trans-Golgi network to yield the disulfide-linked heterodimer $\mathrm{F}_{2}-\mathrm{F}_{1}$ (Collins et al., 2001). The $\mathrm{F}$ protein induces neutralizing antibodies and confers resistance to BRSV infection (Taylor et al., 1992; Taylor et al., 1997; Thomas, et al., 1998; Taylor et al., 2005). The F protein in BRSV is 574 AA in length (Lerch et al., 1990; Pastey et al., 1993) and is highly conserved between different BRSV isolates.

The objectives of the present work were to clone the transmembrane glycoproteins $\mathrm{G}$ and $\mathrm{F}$ from a Brazilian BRSV isolate (antigenic subgroup B) in a prokaryotic system, to examine the nucleotide sequences on the conserved central region $G$ and on particular sites of the $F$ protein in BRSV, furthermore, to show mutations which 
are located in the conserved central region $G$ protein demonstrated in previous work and to examine whether there were mutations on the $\mathrm{F}$ protein gene.

\section{MATERIAL AND MEHTODS}

The Brazilian strain BRSV-25-BR (Arns et al., 2003), was propagated in CRIB cells (Flores and Donis, 1995), a clone of MDBK cells resistant to the infection with BVDV, which is highly susceptible to the infection with BRSV (Flores and Donis, 1995; Spilki et al., 2006b). Cells were cultivated in Eagle's minimal essential medium (E-MEM) supplemented with $10 \%$ of Fetal Bovine Serum, free of antibiotics following routine protocols, and titrated through the visualization of syncytia formation in an inverted microscope (Zeiss Axyovert ${ }^{\mathrm{TM}}$, Oberkochen, Germany).

RNA was extracted from infected CRIB cultures using High Pure Viral Nucleic extraction kit ${ }^{\mathrm{TM}}$ (Roche Diagnostics ${ }^{\mathrm{TM}}$, Manheim, Germany). cDNA was synthesized using SuperscriptIII FirstStrand Synthesis Super Mix ${ }^{\mathrm{TM}}$ (Invitrogen Ltd., California, USA) following kit instructions for use with random hexamers. Primer oligonucleotides were originally designed for the present work. PCR of BRSV genes were amplified using specific primers designed for the 3' and 5' flanking regions of the G protein gene, which was the target for polymerase chain reaction. The forward primer BRSVG5 (5' ATG TCC AAC CAT ACC CAC CAT CT 3'); the reverse primer BRSVG3 (5' GGT GAA GAG AGG ATG CCT TG 3') corresponding to amplified products of $752 \mathrm{bp}$.

For the $\mathrm{F}$ protein gene the forward primer BRSVF5 (5' ATA AGG ATG GCG ACA ACA GC 3'was used, annealing to the 3' $\mathrm{F}$ protein gene flanking region); the reverse primer BRSVF3 (5' AGG CCA GGC TTT GGT TTA TT 3'), near to the 5' $\mathrm{F}$ protein gene flanking region, corresponds to amplified products of 1538 bp.

PCR was done in a $5 \mu \mathrm{L}$ mixture containing $2.5 \mu \mathrm{L}$ of $10 \mathrm{X}$ PCR buffer $(10 \mathrm{~m} \mu$ Tris- $\mathrm{HCl} \mathrm{Ph}$ 8.0, $50 \mathrm{~m} \mu \mathrm{KCl}$ and $0.2 \mathrm{~m} \mu \mathrm{MgCl} 2), 1 \mu \mathrm{L}$ of a $10 \mathrm{~m} \mu$ dNTPs mixture, $10 \mathrm{~m} \mu$ of each primer, $2.5 \mathrm{~mL}$ of cDNA, and $0,2 \mu \mathrm{L} \quad(5 \mathrm{U} / \mu \mathrm{L})$ of Platinum $^{\mathrm{TM}}$ High Fidelity DNA Polymerase
(Invitrogen Ltd., California, USA). The amplification was pre-heated for $5 \mathrm{~min}$ at $95^{\circ} \mathrm{C}$, following for 35 cycles, each of them composed of $1 \mathrm{~min}$ at $94^{\circ} \mathrm{C}$ (denaturation), $1 \mathrm{~min}$ at $56^{\circ} \mathrm{C}$ (annealing), and $1 \mathrm{~min}$ at $72^{\circ} \mathrm{C}$ (extension). After the completion of the 35 cycles, a final extension of $7 \mathrm{~min}$ at $72^{\circ} \mathrm{C}$ was performed. Amplifications were carried out in a thermal cycler PCR System 9700 (Gene Amp, Applied Biosystems, PerkinElmer, California, USA). The PCR products were run on $1 \%$ agarose gel and visualized under UV light after being stained with ethidium bromide.

The cloning of PCR product $\mathrm{G}$ and $\mathrm{F}$ genes was performed by using the plasmid vector pCR ${ }^{\circledR} 8 / \mathrm{GW} / \mathrm{TOPO}{ }^{\circledR} \mathrm{TA}$ Cloning ${ }^{\circledR}$ (Invitrogen Ltd., California, USA), procedures were performed according to the manufacturer's instructions.

The cloning reactions pTOPOG and pTOPOF, which transformed pCR ${ }^{\circledR} 8 / \mathrm{GW} / \mathrm{TOPO}{ }^{\circledR}$ TA Cloning ${ }^{\circledR}$ construct into competent Escherichia coli DH5 $\alpha$ (Clontech, Heidelberg, Germany), following the transform heat-shock. The bacterial colonies containing recombinant plasmids were selected in LB medium containing antibiotic spectinomycin (Sigma) and the plasmid DNA was extracted and purified using by Kit PureLink $^{\mathrm{TM}}$ Quick Plasmid Miniprep Kit (Invitrogen Ltd., California, USA), according to the manufacturer's instructions. The presence inserts pTOPOG and pTOPOF, were confirmed by PCR, following the protocol described.

The confirmation of the identity and orientation inserts, the PCR products and PTOPOG and pTOPOF were sequenced using specific primers $\mathrm{G}$ and $\mathrm{F}$ genes and primers M13 vector were sequenced three times each, both in forward and reverse directions using ABI PRISM Big Dye Terminator Cycle Sequencing Ready Reaction kit (Applied Biosystems ${ }^{\mathrm{TM}}$ ).

The BioEdit software, version 7.0.5.2 (Hall, 1999), was used to manipulate the nucleotide sequences. Nucleotide alignments were performed using the Clustal W software, version 1.83 (Thompson et al., 1994). Similarity to the PCR products and inserts with complete gene sequences are deposited in GenBank (http://www.ncbi.nlm.nih.gov/Genbank/index.ht $\mathrm{ml}$ ). The BRSV nucleotide sequences and 
pTOPOG and pTOPOF nucleotide sequences obtained were submitted to the GenBank with access numbers FJ543090 and FJ543091.

\section{RESULTS AND DISCUSSION}

The obtained PCR products (Figure 1) were cloned into vector pTOPO generating pTOPOG and pTOPOF. The nucleotide sequences $\mathrm{G}$ and $\mathrm{F}$ genes were obtained through the partial sequencing of the plasmids pTOPOG and pTOPOF with primer M13. Obtained nucleotide sequences were compared with homolog sequences deposited at GenBank using the NCBI BLAST N program (http://blast.ncbi.nlm.nih.gov/Blast.cgi). The similarity sequences have demonstrated the higher degree homology $98 \%$ for $\mathrm{G}$ protein gene and $96 \%$ for $\mathrm{F}$ protein gene, thus confirming the identity of the target genomic inserts.

Some differences were observed in the deduced amino acid level on the immunodominant region of the $\mathrm{G}$ gene. The two cysteins in positions 173 and 176 of the amino acid sequence were replaced by alanine residues, and there were also other substitutions at this site: $\operatorname{Ser}^{174}$ was replaced by another alanine, $\mathrm{Thr}^{175}$ was substituted for a hystidine and $\mathrm{Glu}^{177}$, and Gly ${ }^{178}$ was replaced by lysine and arginine residues, respectively (Spilki et al., 2006c). The amino acid changes were examined for putative structural changes on the central domain of the protein, and the result is that a major substitution occurred in the cystine-noose coding region of the Brazilian strain BRSV-25-BR of the G protein (Spilki et al., 2006c).

The mutations described earlier for the $G$ gene protein based on a smaller fragment which was sequenced directly from PCR products were now confirmed using plasmid-cloning based sequencing. No relevant mutations were found on the $\mathrm{F}$ protein gene.

In this work the cloning and prokaryotic sistem was described for the transmembrane glycoproteins $\mathrm{G}$ and $\mathrm{F}$ of BRSV, wich are the main targets of immune response. The neutralizing antibodies are induced by $\mathrm{G}$ and $\mathrm{F}$ proteins, as evaluated in calves vaccinated with recombinant vaccinia viruses (rVV) encoding these proteins. The high titre of neutralizing antibodies are induced by $\mathrm{F}$ protein, but only a low level of complement-dependent neutralizing antibodies are induced by $\mathrm{G}$ protein (Taylor et al., 1997; Thomas et al., 1998). These antibodies provide predominantly strain-specific immunity, although recombinant vaccines which express only $G$ protein BRSV are able to induce complete protective immunity of the lower and to a lesser extent upper respiratory tract (Shirijver et al., 1996; Taylor et al., 1998).

The ability to manipulate the genome of BRSV may increase the understanding of the role of different proteins in the pathogenesis of this virus in calves and has provided opportunities for the development of stable, live attenuated virus vaccines, vector vaccines and DNA vaccines. Especially regarding the $G$ protein of the isolate presently cloned, this may be useful to check whether particular features of this protein in such viral isolate may play a biological role or not, since previous work has shown that there is a major mutation between amino acid residues 173 and 178, within the central hydrophobic conserved region, exactly on the site of two of the four cysteine-noose forming cysteine residues, which may interact with the cellular receptor (Valarcher et al., 2000) and plays an important role in the induction of antiviral host immunity (Langedijk et al., 1997).

It may be speculated that the mutations presented by BRSV-25-BR G protein may have been induced by the presence of active and passive naturally acquired immune response against viral infection itself, and the virus may have been selected by infection animals processing antibodies to the virus, which selects antibody escape mutants, as demonstrated in vitro for hRSV (Martinez et al., 1997; Melero et al., 1997; Spilki et al., 2006c).

Despite these alterations on the central hydrophobic region of the attachment protein, this virus infects calves efficiently under experimental conditions inducing moderate lesions on the lungs of infected animals (Almeida et al., 2005; Spilki et al., 2006c).

An optimal BRSV vaccine would combine genetic stability, satisfactory growth in vitro, high attenuation in vivo and a satisfactory level of immunogenicity. Future studies with recombinant viruses represent a particularly 
promising avenue for the development of vaccines and research, expressing antigens by virus vectors has proven to be a productive approach for studying in vitro and in vivo immune responses. An important feature of almost all recombinant viruses is the ability to induce not only humoral, but also cell-mediated immunity (Imler, 1995). Another possible use for the genes cloned on the present work may be as tools for the construction of recombinant vaccine candidates aiming BRSV immunization.

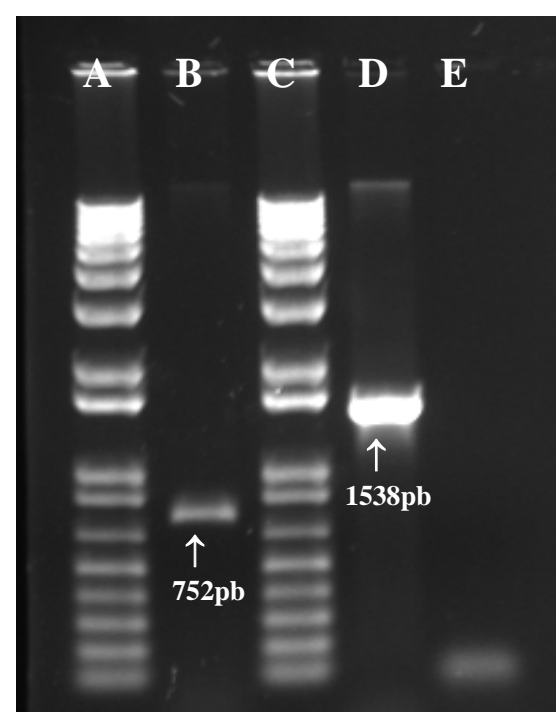

Figure 1. Bovine respiratory syncytial virus $G$ and $\mathrm{F}$ gene amplification. RT-PCR was performed in RNA extracted from strain BRSV25-BR infected CRIB cells for $G$ and $F$ genes. $1 \%$ agarose gel and visualized under UV light after being stained with ethidium bromide. A. 1Kb DNA Ladder (Invitrogen Ltd., California, USA); B. strain BRSV-25BR G gene; C. 1Kb DNA Ladder (Invitrogen Ltd., California, USA); B - strain BRSV-25BR F gene and E. Reaction control.

\section{ACKNOWLEDGEMENTS}

The authors thank Fundação de Amparo à Pesquisa do Estado de São Paulo for Doctoral scholarship, process number 2007/07003-4, and Geneci F. Davi, Paula S. S. Porto and Daniela Stancato for technical assistance.

\section{REFERENCES}

ALMEIDA, R.S.; SPILKI, F.R.; ROEHE, P.M. et al. Detection of Brazilian bovine respiratory syncytial virus strain by a reverse transcriptasenested-polymerase chain reaction in experimentally infected calves. Vet. Microbiol., v.105, p.131-135, 2005.

ARNS, C.W.; CAMPALANS, J.; COSTA, S.C.B. et al. Characterization of bovine respiratory syncytial virus isolated in Brazil. Braz. J. Med. Biol. Res., v.36, p.213-218, 2003.

BASTIEN, N.; TAYLOR, G.; THOMAS, L.H. et al. Immunization with a peptide derived from the G glycoprotein of bovine respiratory syncytial virus (BRSV) reduces the incidence of BRSV associated pneumonia in the natural host. Vaccine, v.15, p.1385-1390, 1997.

BUCHHOLZ, U.J., GRANZOW, H., SCHULDT, $\mathrm{K}$. et al. Chimeric bovine respiratory syncytial virus with glycoprotein gene substitutions from human respiratory syncytial virus (hRSV): effects on host range and evaluation as a live-attenuated hRSV vaccine. $J$. Virol., v.74, p.1187-1199, 2000.

COLLINS, P.L.; CHANOCK, R.M.; MURPHY, B.R. Respiratory syncytial virus. In: KNIPE, D.M.; HOWLEY, P.M. (Eds.). Fields virology, 4.ed. Philadelphia: Lippincott-Williams and Wilkns, 2001. p.1443-1486.

DORELEIJERS, J.F.; LANGEDIJK, J.P.; HARD, K. et al. Solution structure of the immunodominant region of protein $\mathrm{G}$ of bovine respiratory syncytial virus. Biochemistry, v.35, p.14684-14688, 1996.

EASTON, A.J.; DOMACHOWSKE, J.B.; ROSENBERG, H.F. Animal pneumoviruses: Molecular genetics and pathogenesis. Clin. Microbiol. Rev., v.17, p.390-412, 2004.

FLORES, E.F.; DONIS, R.O. Isolation of a mutant MDBK Cell-Line resistant to bovine viral diarrhea virus-infection due to a block in viral entry. Virology, v.208, p.565-575, 1995.

HALL, T.A. BioEdit: a user-friendly biological sequence alignment editor and analysis program for Windows 95/98/NT. Nucl. Acids Symp. Ser., v.41, p.95-98, 1999. 
IMLER, J.L. Adenovirus vectors as recombinant viral vaccines. Vaccine, v.13, p.1143-1151, 1995.

KARGER, A.; SCHMIDT, U.; BUCHHOLZ, U.J. Recombinant bovine respiratory syncytial virus with deletions of the G or SH genes: G and F proteins bind heparin. J. Gen. Virol., v.82, p.631-640, 2001.

LANGEDIJK J.P.; SCHAAPER, W.M.; MELEON, R.H. et al. Proposed threedimensional model for the attachment protein $G$ of respiratory syncytial virus. J. Gen. Virol., v.77, p.1249-1257, 1996.

LANGEDIJK J.P.; MELEON, R.H.; TAYLOR, $\mathrm{G}$. et al. Antigenic structure of the central conserved region of protein $G$ of bovine respiratory syncytial virus. J. Virol., v.243, p.293-302, 1997.

LARSEN, L.E. Bovine respiratory syncytial virus (BRSV): a review. Acta Vet. Scand., v.41, p.1-21, 2000.

LERCH, R.A.; ANDERSON, K.; WERTZ, G.W. Nucleotide sequence analysis and expression from recombinant vectors demonstrate that the attachment protein $\mathrm{G}$ of bovine respiratory syncytial virus. J. Virol., v.64, p.5559-5569, 1990.

LEVINE, S.; KLAIBER FRANCO, R.; PARADISO, P.R. Demonstration that glycoprotein $G$ is the attachment protein of respiratory syncytial virus. J. Gen. Virol., v.68, p.2521-2524, 1987.

MARTINEZ, I.; DOPAZO, J.; MELERO, J.A. Antigenic structure of the human respiratory syncytial virus $G$ glycoprotein and relevance of hypermutation events for the generation of antigenic variants. J. Gen. Virol., v.74, p.20012004, 1997.

MELERO, J.A.; GARCIA-BARRENO, B.; MARTINEZ, I. et al. Antigenic structure, evolution and immunobiology of human respiratory syncytial virus attachment (G) protein. J. Gen. Virol., v.78, p.2411-2418, 1997.

PACCAUD, M.F.; JACQUIER., C.A Respiratory syncytial virus of bovine origin. Archiv. Gesamte Virusforschung, v.30, p.327, 1970.
PASTEY, M.K.; SAMAL, S.K. Structure and sequence comparison of bovine respiratory syncytial virus fusion protein. Virus Res., v.29, p.195-202, 1993.

SCHRIJVER, R.S.; LANGEDIJK, J.P.M.; vander POEL, J.P.M. et al. Antibody responses against the $G$ and $F$ proteins of bovine respiratory syncytial virus after experimental and natural infections. Clin. Diagn. Lab. Immunol., v.3, p.500-506, 1996.

SPILKI, F.R.; ALMEIDA, R.S.; DOMINGUES, H.G. et al. Phylogenetic relationships of Brazilian bovine respiratory syncytial virus isolates and molecular homology modeling of attachment glycoprotein. Virus Res., v.116, p. 30-37, 2006a.

SPILKI, F.R.; ALMEIDA, R.S.; CAMPALANS, J. et al. Susceptibility of different cell lines to infection with bovine respiratory syncytial virus. J. Virol. Methods, v.131, p.130-133, 2006b.

SPILKI, F.R.; ALMEIDA, R.S.; FERREIRA, H.L. et al. Effects of experimental inoculation of bovine respiratory syncytial virus in different inbred mice lineages: Establishment of a murine model for BRSV infection. Vet. Microbiol., v.118, p.161-168, 2006c.

STINE, L.C.; HOPPE, D.K.; KELLING, C.L. Sequence conservation in the attachment glycoprotein and antigenic diversity among bovine respiratory syncytial virus isolates. Vet. Microbiol., v.54, p.201-221, 1997.

TAYLOR, G.; STOTT, E.J.; FURZE, J. et al. Protective epitopes on the fusion protein of respiratory syncytial virus recognized by murine and bovine monoclonal antibodies. J. Gen. Virol., v.73, p.2217-2223, 1992.

TAYLOR, G.; THOMAS, L.H.; FURZE, F.A.M. et al. Recombinant vaccinia viruses expressing the $\mathrm{F}, \mathrm{G}$ or $\mathrm{N}$, but not the M2, protein of bovine respiratory syncytial virus (BRSV) induce resistance to BRSV chalengee in the calf and protest against the development of pneumonic lesions. J. Gen. Vilrol., v.78, p.3195-3206, 1997.

TAYLOR, G.; RIJSEWIJK, F.A.M.; THOMAS, L.H. et al. Resistance to bovine respiratory syncytial virus (BRSV) induced in calves by a recombinant bovine herpesvirus-1 expressing the attachament glycoprotein of BRSV. J. Gen. Virol., v.79, p.1759-1767, 1998. 
TAYLOR, G.; BRUCE, C.; BARBET, A.F. et al. DNA vaccination against respiratory syncytial virus in young calves. Vaccine, v.23, p.12421250, 2005.

TECHAARPORNKUL, S.; BARRETTO, N.; PEEPLES, M.E. Functional analysis of recombinant respiratory syncytial virus deletion mutants lacking the small hydrophobic and/ or attachment glycoprotein gene. J. Virol., v.75, p.6825-6834, 2001.

TENG, M.N.; COLLINS, P.L. The central conserved cystine noose of the attachment G protein of human respiratory syncytial virus is not required for efficient viral infection in vitro or in vivo. J. Virol., v.76, p.6164-6171, 2002.

THOMAS, L.H.; COOK, R.S.; WYLD, S.G. et al. Passive protection of gnotobiotic calves using monoclonal antibodies at different epitopes on the fusion protein of bovine respiratory syncytial virus. J. Infect. Dis., v.177, p.874-880, 1998.

THOMPSON, J.D.; HIGGINS, D.G.; GIBSON, T.J. Clustal W: improving the sensitivity of progressive multiple sequence alignment through sequence weighting, position-specific gap penalties and weight matrix choice. Nucleic Acids Res., v.22, p.4673-4680, 1994.
VAINIONPÄÄ, R.; MARUSYK, R.; SALMI, A. The Paramyxoviridae aspects of molecular structure, pathogenesis, and immunity. Adv. Virus Res.. v.37, p.211-242, 1989.

VALARCHER, J.F.; SCHELCHER, F.; BOURHY, H. Evolution of bovine respiratory syncytial virus. J. Virol., v.74, p.10714-10728, 2000.

VALARCHER, J.F.; TAYLOR, G. Bovine respiratory syncytial virus infection. Vet. Res., v.38, p.153-180, 2007.

VALENTOVA, V. The antigenic and genetic variability of bovine respiratory syncytial virus with emphasis on the G protein. Med., Czech, v.48, p.254-266, 2003.

WERTZ, G.W.; COLLINS, P.L.; HUANG, Y. et al. Nucleotide sequence of the $G$ protein gene of human respiratory syncytial virus reveals an unnsual type of viral membrane protein. Proc. Natl. Acad. Sci., USA, v.82, p.4075-4079, 1985.

www.ncbi.nlm.nih.gov/Genbank/index.html 